Research Article

\title{
Grinding Technique on Synthesis of Calixarene and Its Derivatives
}

\author{
Susy Yunita Prabawati ${ }^{1, *}$, Afifah Mufidati ${ }^{1}$, Titis Ratna Djuwita ${ }^{1}$, Siti Nur Ngaini ${ }^{1}$ \\ 1 Chemistry Study Program, Faculty of Science and Technology, Universitas Islam Negeri (UIN) \\ Sunan Kalijaga Yogyakarta, J1. Laksda Adi Sucipto Yogyakarta 55281 Indonesia \\ * Corresponding author: susyprabawati@gmail.com
}

Received: 11 June 2020; Accepted: 4 July 2020; Published: 12 July 2020

\begin{abstract}
The synthesis of p-t-butylcalix[6]arene (PK[6]A) and calixresorcinarene derivative compounds, namely C-para-dimethylamino-phenylcalix[4]resorcinarene (CPDAK[4]R) and C-4-hydroxyphenylcalix[4]-resorcinarene $(\mathrm{CHK}[4] \mathrm{R})$, had been carried out by grinding technique. The grinding technique was done with the absence of solvents so that it minimized the waste. Synthesis occurred through electrophilic substitution reactions with $\mathrm{KOH}$ as an alkaline catalyst and p-toluene sulfonic acid as an acid catalyst. The three calixarene products were in the form of crystalline solids with a melting point of more than $300^{\circ} \mathrm{C}$, insoluble in water with yields of $62.58 ; 61.94$ and $97.49 \%$, respectively. Product characterization using FTIR analysis showed the vibration of the methylene bridge $\left(-\mathrm{CH}_{2}^{-}\right)$at a wavenumber of $1473.62 \mathrm{~cm}^{-}$ ${ }^{1}$ and LC-MS analysis for (PK[6]R) showed that the molecular weight was $974.77 \mathrm{~g} / \mathrm{mole}$. While the analysis of (CPDAK [4]R) and (CHK[4]R) with ${ }^{1} \mathrm{H}$ NMR showed the presence of protons from the methine bridge ($\mathrm{CH}-)$ that appear at the chemical shift of 4.950 and $3.078 \mathrm{ppm}$.
\end{abstract}

Keywords: $\quad$ p-t-butilkaliks[6]arena (PK[6]A), C-para-dimetil-amino-fenilkaliks[4]resorsinarena (CPDAK[4]R), C-4-hidroksi-fenilkaliks[4]resorsinarena (CHK[4]R,), grinding technique

\section{Introduction}

Calixarene is a synthetic oligomer containing an aromatic ring (phenol or resorcinol) in a cyclic series which is connected by methylene or methine bridge [1]. This condition creates the compound resembles the bowl or basket. Its unique geometric structure makes this compound can be used as guest-host and widely employed for various purposes, such as catalysts [2], sunscreens [3], heavy metal extractants [4], inorganic material crust inhibitors [5], and heavy metal adsorbents [6, 7].

Calixarene macrocyclic can be synthesized from aromatic compounds-basic material, both either phenol derivatives and resorcinol. Modifications can be made at the type and number of aromatic units, aldehyde types both aliphatic and aromatic aldehydes [1] or functional group modification with almost unlimited variation [8].

Calixarene compound synthesis is commonly fabricated by a conventional method, reflux. However, this method requires a long time and a large amount of solvent. A solvent-free method, or better known as grinding, is recently widely employed in chemical reactions [9]. The reaction result depends on the collision process without involving heating [10].

The uses of the grinding techniques in the synthesis of several calixarene compounds have been reported, i.e. the synthesis of calix[4]resorcinarene [11], pyrogallol[4]arene [9] and pillar[6]arene [12]. This technique provides advantages, such as effective and environmentally friendly production because of the less amount of waste resulting from the use of fewer solvents [13].

This work reports the synthesis of p-t-butilcalix[6]arene (PK[6]A) from p-t-butyl-phenol and the derivative compounds of calixresorcinarene, i.e. C-para-dimethilamino-phenylkaliks[4]resorcininar (CPDAK[4]R) and C-4-hydroxyphenylcalcid [4]resorcinarene (CHK[4]R) by grinding technique. Figure 1 shows the general reaction of calixarene synthesis. 


\section{Materials and Methods}

\section{Methods}

p-t-butylphenol, formaldehyde 37\%, $\mathrm{KOH}$, resorcinol, 4-hydroxy benzaldehyde, methanol, 4dimethyl-amino-benzaldehyde (PDAB), p-toluene-sulfonic acid, $\mathrm{CrCl}_{3} .6 \mathrm{H}_{2} \mathrm{O}, \mathrm{Pb}\left(\mathrm{NO}_{3}\right)_{2}, \mathrm{HNO}_{3}, \mathrm{NaOH}$ and distilled water.

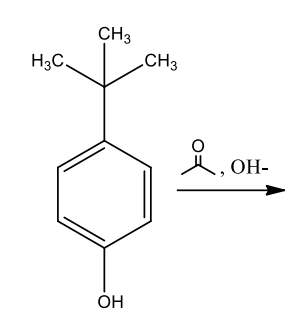

$p$-t-butylphenol

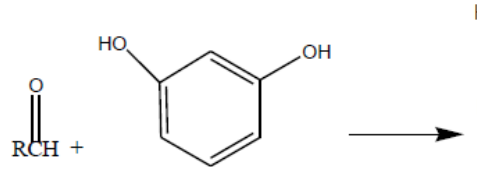

resorcinol

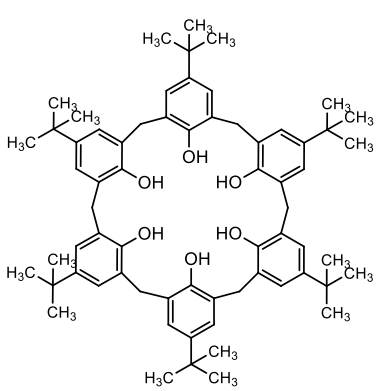

(a)

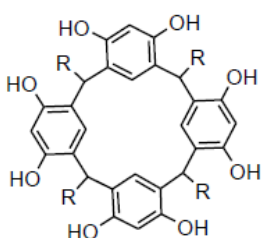

(b)

Figure 1. General synthesis reaction of (a) p-t-butylca

ene and (b) calix[4]resorcinarene Apparatus

Mortar, pestle, beaker glass $10 \mathrm{~mL}$, watch glass, ox-horn spoon, filter paper, dropper, hot plate, magnetic stirrer, aluminum paper, $\mathrm{pH}$ indicator, $\mathrm{pH}$ meter CONSORT C931, analytical balance, funnel Buchner, oven, melting point apparatus Electrothermal 9100 Digital Model, shaker water bath, FTIR Shimadzu Pretige 21 spectrophotometer, Perkin Elmer 3110 Atomic Absorption Spectrophotometer (AAS), Liquid Chromatography-Mass Spectrophotometry (LC-MS) Water Alliance 2695 and 1H-NMR spectrometry JEOL-JNM-ECZ500R/S1.

\section{Procedure}

\section{PK[6]A Synthesis}

A paste was made from $1.8 \mathrm{~g}$ or 0.012 mole of $p$-t-butylphenol and 0.45 equivalent of catalyst of $\mathrm{KOH}$ which were crushed in a mortar and added by $1.5 \mathrm{~mL}$ of preheated formaldehyde $37 \%$. Hereafter, the paste was left for 1 hour then it washed by distilled water, filtered and heated at $60{ }^{\circ} \mathrm{C}$. The solids obtained were recrystallized with sufficient methanol. The product was tested for its purity by melting point measurement and characterization was carried out using FTIR and LC-MS instruments.

\section{(CPDAK[4]R) and (CHK[4]R) compounds}

Synthesis of CPDAK[4]R was conducted by adding $0.07 \mathrm{~g}$ of $p$-toluenesulfonic acid and $0.33 \mathrm{~g}$ or 0.003 moles of resorcinol into $0.45 \mathrm{~g}$ or 0.003 moles of PDAB. Synthesis of CHK[4]R was carried out by mixing $0.6 \mathrm{~g}$ ( 0.003 moles) of 4-hydroxy benzaldehyde, 0.1 gram ( 0.005 moles of catalyst p-toluene sulfonate) and $0.5 \mathrm{~g}(0.003$ moles $)$ of resorcinol and they were crushed in a porcelain mortar. The next step was carried out like the process of PK[6]A synthesis. Furthermore, the products were measured its melting point and characterized by FTIR and ${ }^{1} \mathrm{H}-\mathrm{NMR}$ spectrophotometer.

\section{Results and Discussion}

\section{Synthesis and characterization of compound}

The synthesis procedure of PK[6]A is based on a conventional method that had been carried out by $[14,15]$, that is by reacting p-t-butylphenol and formaldehyde in an alkaline condition. The distinguishing procedure in this study is in the synthesis process that using grinding, without solvent and heating process. 
The reaction occurred through an aromatic electrophilic substitution reaction, and the product obtained was a yellowish-brown crystal, insoluble in water, soluble in methanol with a yield of $62.58 \%$.

The synthesis of CPDAK[4]R and CHK[4]R was executed in acid condition with the presence of catalyst, p-toluenesulfonic acid. The ratio of reagents used was 1:1 (mole). CPDAK[4]R product obtained was in the form of chocolate crystal with a yield of $61.94 \%$. The result is much better than previous research using reflux method [16] with the yield of $13.67 \%$. Meanwhile, the CHK[4]R product obtained in this research consisted of brownish-red crystals, with a yield of $97.49 \%$. It was better than previous reseach [17] with a yield of $93.45 \%$ of the product which the method using reflux method and various kinds of solvents at $80^{\circ} \mathrm{C}$ for 17 hours. Therefore, the grinding technique had proven to be more effective for calixarene synthesis with shorter time of reaction time, more yield obtained, less waste produced because of solventfree in the synthesis.

The melting point test result of the three compounds exhibited that the crystal had not melted at 300 ${ }^{\circ} \mathrm{C}$. This is in line with the literature showing that calixarene compounds have a high melting point of around $380-381^{\circ} \mathrm{C}$ [14]. FTIR spectrophotometry was employed to characterize three calixarene products and the spectra are shown in Figure 2.

The success of calixarene synthesis was indicated by the formation of a methylene bridge that appears at a wavenumber of around $1400 \mathrm{~cm}^{-1}$. Also, the absence of the aldehyde group $(\mathrm{C}=\mathrm{O})$ at wavenumber of $1700 \mathrm{~cm}^{-1}$ and $\mathrm{C}-\mathrm{H}$ aldehyde at 2850 and $2750 \mathrm{~cm}^{-1}$ indicate the disappearance of aldehyde groups as the characteristic of one of the reagents used. More detail can be seen in Table 1.

Further characterization had been done using LC-MS for (PK [6]R) and ${ }^{1} \mathrm{H}-\mathrm{NMR}$ and (CPDAK[4]R) and $(\mathrm{CHK}[4] \mathrm{R})$ to ensure the formation of the target compounds. LC-MS analysis shows the molecular weight $(\mathrm{m} / \mathrm{z})$ of $(\mathrm{PK}[6] \mathrm{R})$ in this study is $974.77 \mathrm{~g} /$ mole. Theoretically, the molecular weight of $(\mathrm{PK}[6] \mathrm{R})$ is $973.4 \mathrm{~g} /$ mole [18]. Its difference might be because of the isotope effect. Ion containing $\mathrm{n}$ carbon atoms is possible to have $1.1 \%$ of ${ }^{13} \mathrm{C}$ atoms which heavier than ${ }^{12} \mathrm{C}$ [19]. Figure 3 shows the fragmentation of (PK[6]R) compound.
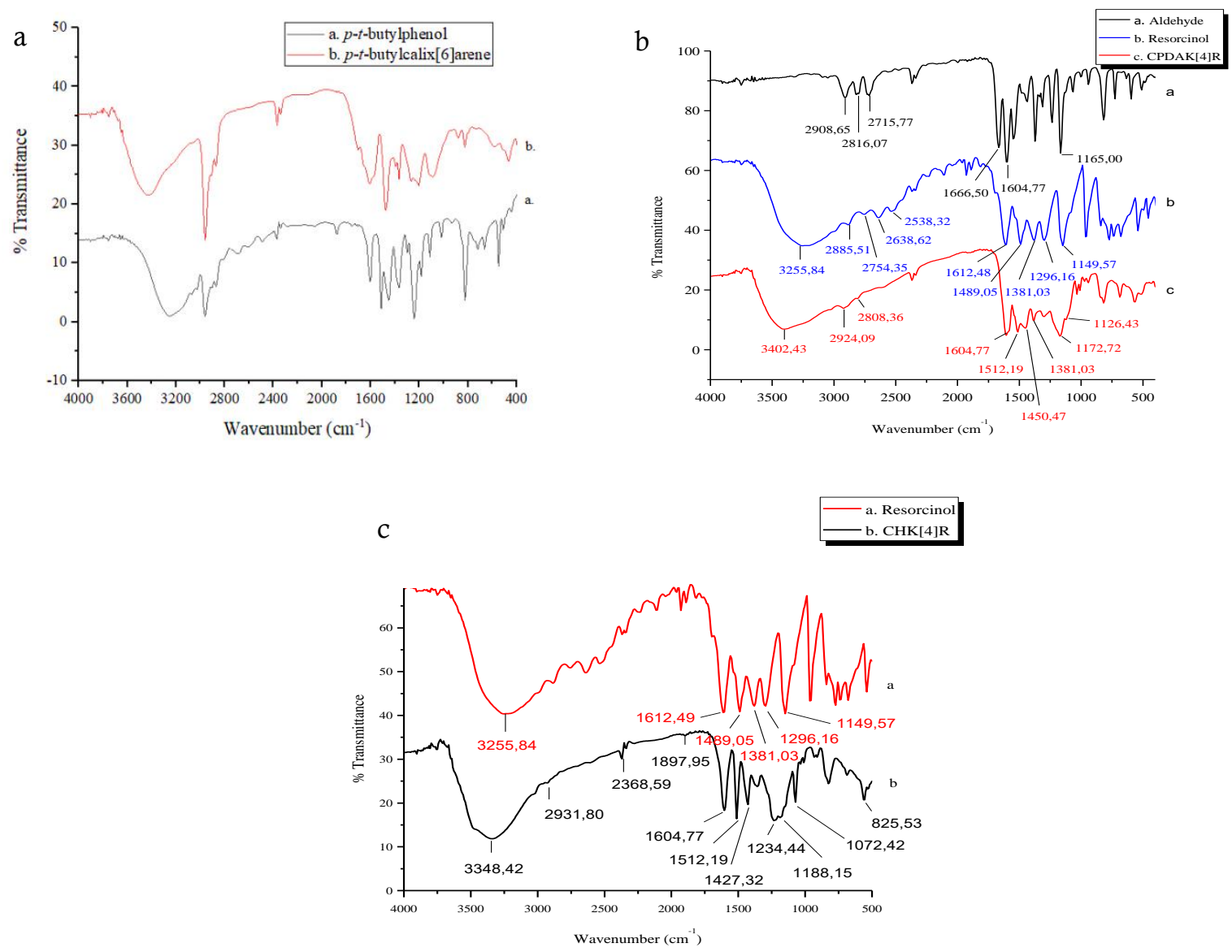

Figure 2. The FTIR spectra of (a)PK[6]R, (b)CPDAK[4]R and (c)CHK[4]R 
Table 1. Analysis of functional group vibration of the synthesized compound

\begin{tabular}{cccc}
\hline Functional group & $\begin{array}{c}\text { PK[6]R } \\
\mathbf{c m}^{-1}\end{array}$ & $\begin{array}{c}\text { CPDAK[4]R } \\
\mathbf{c m}^{-1}\end{array}$ & $\begin{array}{c}\mathbf{C H K} \text { [4] } \\
\mathbf{c m}^{-1}\end{array}$ \\
\hline$-\mathrm{CH}_{2^{-}}$ & 1473.62 & - & - \\
$-\mathrm{CH}-$ & - & 1450,47 & 1427.32 \\
$-\mathrm{OH}$ & 3425.58 & 3402,43 & 3348.42 \\
$\mathrm{C}=\mathrm{C}$ aromatic & 1604.77 & 1604.77 and 1512.19 & 1604.77 and 1512.19 \\
$t$-butil $\left[\mathrm{C}\left(\mathrm{CH}_{3}\right)_{3}\right]$ & 1365.60 & - & - \\
$\mathrm{C}-\mathrm{N}$ amina & - & 1172,72 & - \\
\hline
\end{tabular}

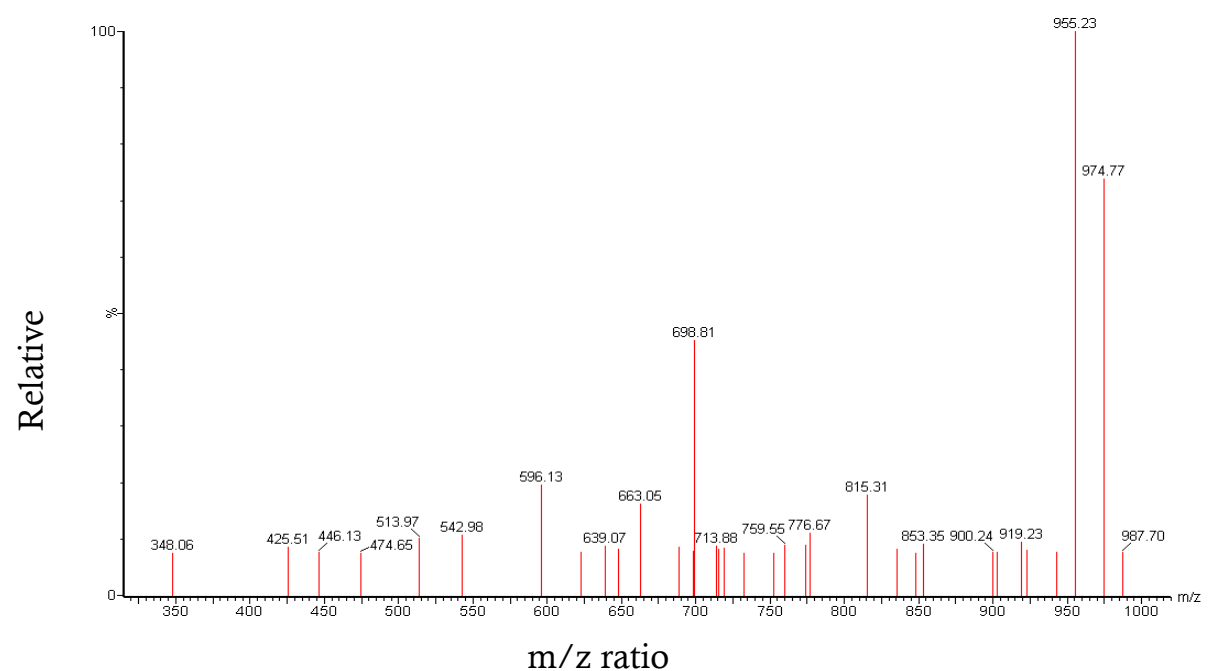

Figure 3. Fragmentation spectra of PK[6]R compound

The fragmentation can represent that the mechanism of the synthesis of $p$-t-butylkaliks[6]arene (Figure 4). Hexameric cyclic compounds were formed through the cyclooligomerization process of the linear hexamer. It is confirmed with the research of Vocanson et al explained in Gutsche that a high amount of the linear hexamer was formed in the synthesis of $p-t$-butylcalix[6]arene [14].

Further characterization of the calixrecorcinarene derivation product, i.e. CPDAK[4]R and CHK[4]R, was studied using ${ }^{1} \mathrm{H}-\mathrm{NMR}$ spectrophotometer to identify the number of proton of the product. The result is shown in Figure 5. The reactions in the synthesis of compounds PK[6]A, CPDAK[4]R and CHK[4]R are electrophilic substitution reactions. An electrophile substituted an atom in the aromatic compound. The replacement by $-\mathrm{OH}$ group in the aromatic compounds $p$-t-butylphenol and resorcinol affected the subtituted atom position because the - $\mathrm{OH}$ group determines the position of ortho or para.

The synthesis of PK[6]A was initiated with the formation of phenoxide ions from $p$-t-butylphenol which reacts with $\mathrm{KOH}$ as the catalyst. The phenoxide ion became a carbon nucleophile and carried out a nucleophilic attack on the carbonyl group of reactive formaldehyde. This condition caused a substitution reaction of an $\mathrm{H}$ atom at the ortho position of the $p$-t-butylphenol aromatic compound to produce hydroxymethylphenol [14]. Furthermore, phenoxide ion was re-formed and a resonance occurred in the ortho position that has bonded with formaldehyde. It caused the form of oligomers connected to the methylene bridge through the release of $\mathrm{H}_{2} \mathrm{O}$. 


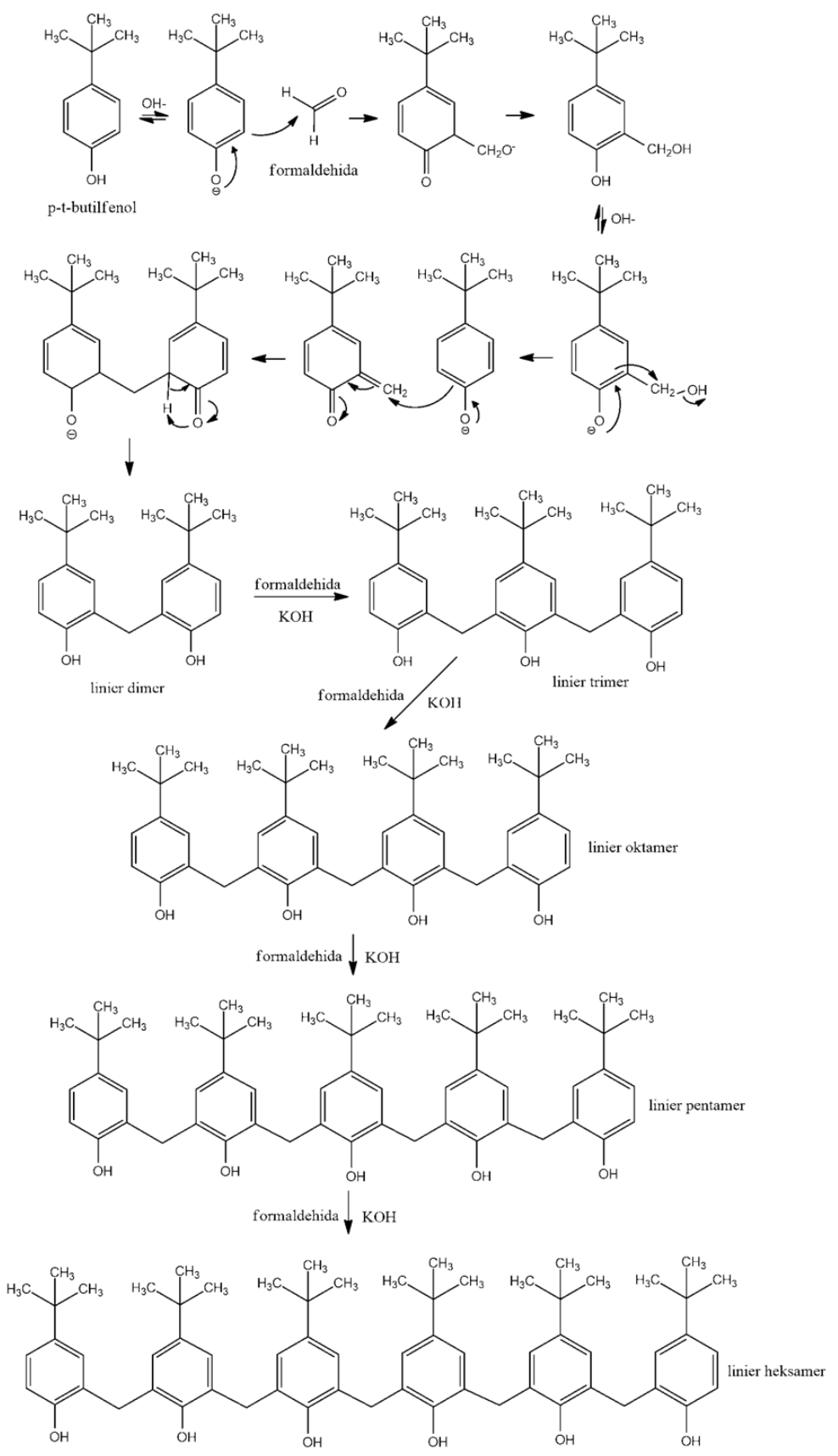

Figure 4. Reaction mechanism of Calix(6)arene formation

The electrophilic substitution reaction in the synthesis of CPDAK[4]R and CHK[4]R were initiated through the protonation step of aldehyde due to acidic condition by the presence of p-toluensulfonic acid as catalyst. It caused the formation of carbocation by aldehyde. The carbocation of the reactive aldehyde substituted one of the $\mathrm{H}$ atoms from the aromatic ring of the resorcinol compound at the ortho or para position. Furthermore, the alcohol hydroxyl group from the aldehyde bridge was re-protonated through the release of $\mathrm{H}_{2} \mathrm{O}$ molecules. The release of $\mathrm{H}_{2} \mathrm{O}$ molecules generated the re-forming of electrophiles. It attacked other resorcinol to form dimers to tetramers resorcinol. 
(a)
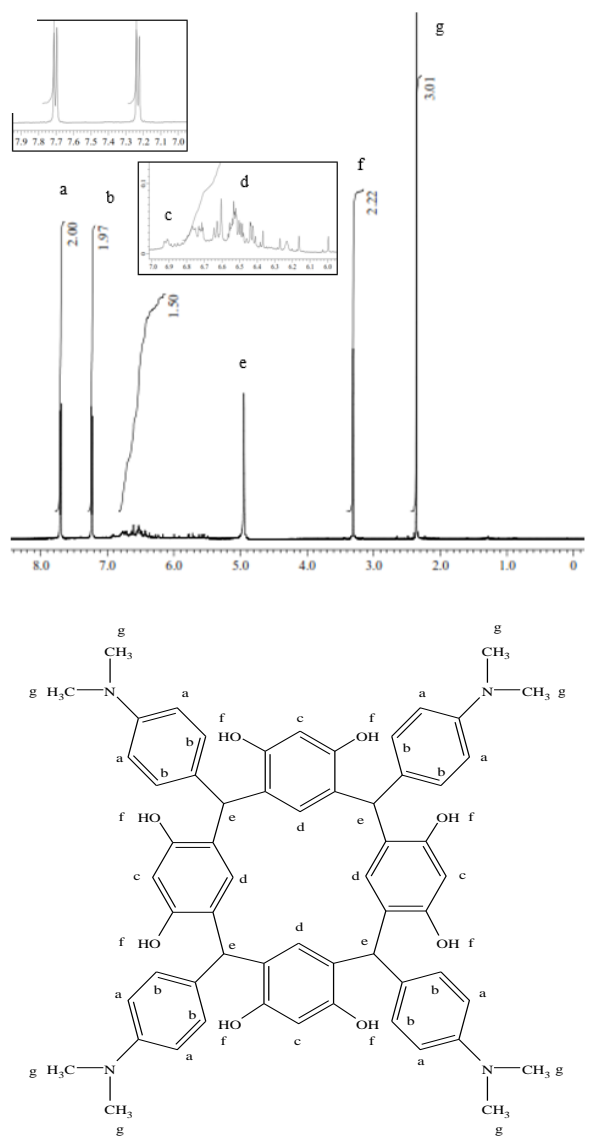

(b)
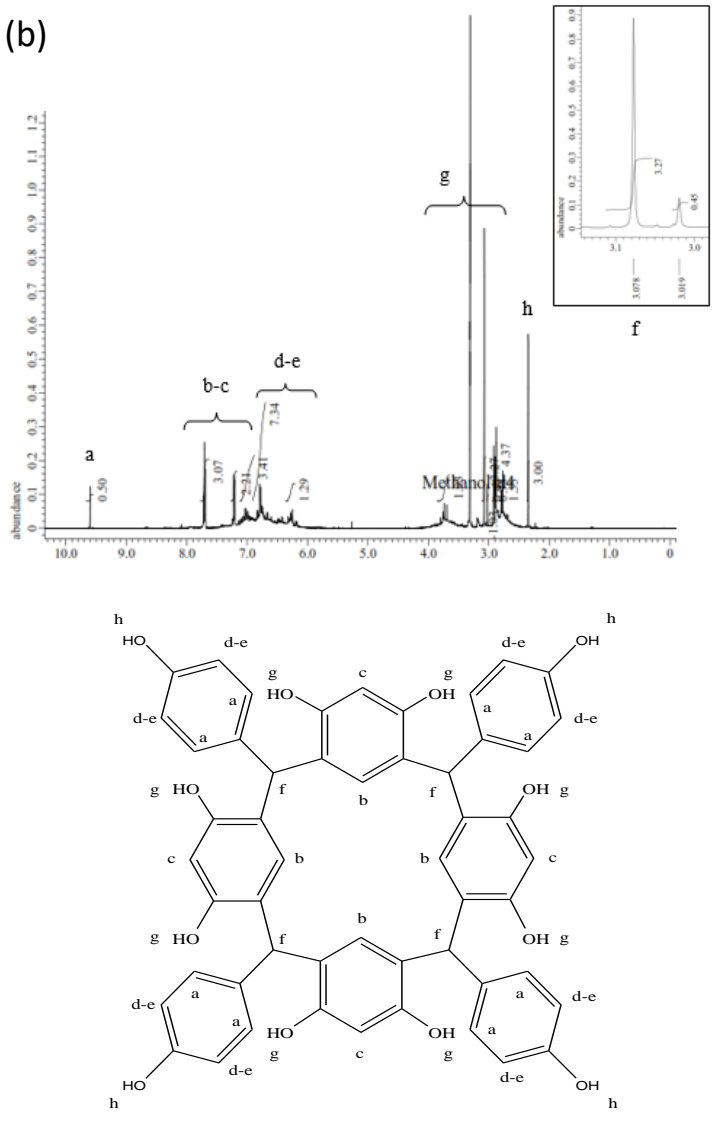

Figure 5. ${ }^{1} \mathrm{H}-\mathrm{NMR}$ spectra and the monomer of (a) CPDAK[4]R and (b) CHK[4]R compound

Table 2. Result of ${ }^{1} \mathrm{HNMR}$ spectra analisis of CPDAK[4]R

\begin{tabular}{ccc}
\hline Peak & $\boldsymbol{\delta}(\mathbf{p p m})$ & Proton identification \\
\hline A & $7,695-7,711$ & C-H aromatic group (a) \\
b & $7,223-7,239$ & C-H aromatic group (b) \\
c and d & $6,521-6,929$ & C-H aromatic group (c and d) \\
E & 4,950 & C-H methin (e) \\
f & 3,310 & hidroksi group (f) \\
G & 2,361 & methyl group (g) \\
\hline
\end{tabular}

Table 3. Result of ${ }^{1} \mathrm{HNMR}$ spectra analisis of $\mathrm{CHK}[4] \mathrm{R}$

\begin{tabular}{ccc}
\hline Peak & $\boldsymbol{\delta} \mathbf{( p p m )}$ & Proton identification \\
\hline A & 9,601 & aromatic C-H group (a) \\
b-c & $7,725-7,205$ & aromatic C-H group (a) \\
d-e & $6,837-6,250$ & aromatic C-H group (d-e), (c), and (b) \\
F & 3,078 & CH bridge (f) \\
G & $3,807-2,765$ & hydroxyl group (g) and (h) \\
H & 2,348 & hydroxyl group (h) \\
\hline
\end{tabular}




\section{Conclusion}

The p-t-butylcalix[6]arene (PK[6]R) compounds had been synthesized by grinding techniques from p-tbutylphenol and formaldehyde in the presence of $\mathrm{KOH}$ as the catalyst. Then, the C-para-dimethyl-aminophenylcalix[4]resorsinarene (CPDAK[4]R) and C-4-hydroxy-phenylcalix[4]recorcinare (CHK[4]R) had been synthesized from the resorcinol in an acidic condition in the presence of p-toluenesulfonic acid as the catalyst. The products were a brownish-yellow crystal with a melting point of more than $300^{\circ} \mathrm{C}$, insoluble in water but soluble in methanol, with a yield of PK[6]R, CPDAK[4]R and CHK[4]R is 62.58; 61.94 and $97.49 \%$, respectively. Compared to conventional techniques, this grinding technique provides more effectiveness in the synthesize of calixarene compounds. It provides faster time, more yield production, and environmentally friendly due to the lack of waste generated.

\section{References}

[1] S.B. Utomo, Rekayasa Molekul Makrosiklis untuk Aplikasi Lingkungan dan Medis. Seminar Nasional Kimia dan Pendidikan Kimia VI, Program Studi Pendidikan Kimia Universitas Sebelas Maret, Surakarta, 2014.

[2] D.L. Silvia, S.A. Fernandees, A.A. Sabino, A. Fatima, P-Sulfonic Acid Calixarenes as Efficient and Reusable Organocatalysts for the Synthesis of 3,4-dihydropyrimidin-2(1H)-ones/-Thiones. Journal homepage: www.elsevier.com/locate/tetlet . Tetrahedron Letters 52 (2011) 6328-6330.

[3] T. Setyawan, Sintesis Senyawa Tabir Surya Turunan Kaliks[4]resorsinarena Benzofenon dari Vanilin. Tesis, Program Studi S2 Ilmu Kimia UGM: Yogyakarta, 2013.

[4] Mukhlasoh, Sintesis Senyawa p-t-Butil-Heksa-Asamkaliks[6]arena dan Penggunaan nya Sebagai Ekstraktan Logam Berat Cr(III). Skripsi, Program Studi Kimia UIN Sunan Kalijaga: Yogyakarta, 2014.

[5] Suharso, Buhani, dan Tugiono, Pembuatan Senyawa Turunan Kaliksarena Untuk Inhibitor Kerak Material Anorganik. Prosiding SEMIRATA 2015 Bidang MIPA BKS-PTN Barat: Universitas Tanjungpura, Pontianak, 2015.

[6] F.N. Hanifa, Sintesis Senyawa p-t-Butil-heksa-esterkaliks[6]arena dan Penggunaannya Sebagai Ekstraktan Logam Berat Cr(III), Skripsi, Program Studi Kimia UIN Sunan Kalijaga Yogyakarta, 2013.

[7] A. Setiawan, Sintesis Senyawa C-Heptil Kaliks[4]resorsinaren Oktaasetat dan Aplikasinya Sebagai Adsorben Ion Logam Berat Cr(III), Skripsi, Program Studi Kimia UIN Sunan Kaliijaga: Yogyakarta, 2016.

[8] S.Y. Prabawati, Jumina, S.J. Santosa, Mustofa, O. Keisuke, Study on the Adsorption Properties of Novel Calix[6]arene Polymers for Heavy Metal Cations, Indo. J. Chem. 12 (1) (2012) 28-34.

[9] J.L. Atwood, Solvent-Free, Direct Synthesis of Supramolecular Nano-Capsules, Chem. Commun. The Royal Society of Chemistry, 892-894, 2005.

[10] R.E. Sardjono, R. Rahmi, Green Sythesis of Oligomer Calixarenes. Pada buku: Green Chemical Processing and Synthesis. Diedit oleh Karame, Iyad and Hassan Srour. Publisher: InTech, 2017.

[11] B.A. Robert, W.V. Gareth, C.L. Raston, J.L Scoot, Solvent-Free Synthesis of Calix[4]recorciarenes. Green Chemistry. The Royal Society of Chemistry, (3) (2001) 280-284.

[12] S. Santra, Solvent-free Synthesis of Pillar[6]arenes, Green Chemistry, The Royal Society of Chemistry, 2015.

[13] S. Sobariah, Penggunaan Metode Solvent-Free Pada Sintesis Tetramer Siklik Kaliks[4]resorsinarena dari 7-Hidroksisitronelal, Skripsi, FMIPA UPI, 2011.

[14] C.D. Gutsche, Calixarenes: An Introduction 2nd Edition. Cambridge: The Royal Society of Chemistry, 2008.

[15] S.Y. Prabawati, Jumina, S.J. Santosa, Mustofa, Synthesis of Polypropylcalix[6]arene from p-tbutylphenol as Adsorbent for Cr(III) Metal Ion, Indo. J. Chem. 11 (1) (2011) 37-42.

[16] D.S. Handayani, R.A. Sholikh, T. Kusumaningsih, Sintesis dan Karakterisasi C-4-hidroksi-3metoksifenilKaliks[4]-resorsinarena Sulfonat, Alchemy Jurnal Penelitian Kimia, 9 (2) (2013) 13-21.

[17] R.E. Sardjono, Sintesis dan Penggunaan Tetramer Siklis Seri Kaliksresorsinarena, Alkoksikaliksarena, dan Alkenimaliksarena Untuk Adsorpsi Kation Logam Berat. Disertasi, Universitas Gajah Mada: Yogyakarta, 2007.

[18] Pubchem, Compound Summary: 4-tert-butylcalix[6]arene. //https: pubchem.ncbi.nlm.nih.gov/ compound/335356\#section=lnChl-Key, 2019.

[19] H. Sastrohamidjojo, Spektroskopi, Yogyakarta: Liberty, 2007. 